City University of New York (CUNY)

CUNY Academic Works

\title{
A Genealogical Review of the Worldview Concept and Framework in Africana Studies-Related Theory and Research
}

Karanja Keita Carroll

CUNY Bernard Baruch College

\section{How does access to this work benefit you? Let us know!}

More information about this work at: https://academicworks.cuny.edu/bb_pubs/1155

Discover additional works at: https://academicworks.cuny.edu

This work is made publicly available by the City University of New York (CUNY).

Contact: AcademicWorks@cuny.edu 


\title{
African American Consciousness
}

\author{
Past and Present
}

\author{
James L. Conyers, Jr., editor
}

Africana Studies, Volume 4

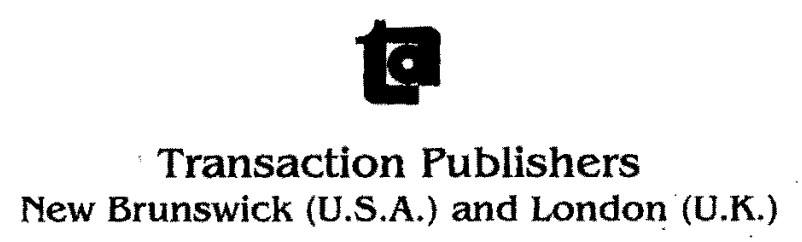


Copyright $\odot 2012$ by Transaction Publishers, New Brunswick, New Jersey.

All rights reserved under International and Pan-American Copyright Conventions. No part of this book may be reproduced or transmitted in any form or by any means, electronic or mechanical, including photocopy, recording, or any information storage and retrieval system, without prior permission in writing from the publisher. All inquiries should be addressed to Transaction Publishers, Rutgers-The State University of New Jersey, 35 Berrue Circle, Piscataway, New Jersey 08854-8042. www.transactionpub.com

This book is printed on acid-free paper that meets the American National Standard for Permanence of Paper for Printed Library Materials.

Library of Congress Catalog Number: 2011017764

ISBN: 978-1-4128-4307-2

Printed in the United States of America

\section{Library of Congress Cataloging-in-Publication Data}

African American consciousness : past and present /

James L. Conyers, Jr.

editor.

p. cm. - (Africana studies ; v. 4)

Includes index.

ISBN 978-1-4128-4307-2 (alk. paper)

1. African Americans-Race identity. 2. African AmericansPolitical activity. 3. African Americans-Social conditions. 4. African Americans-Study and teaching. I. Conyers, James L.

E185.625.A368 2011

973:0496073-dc23

2011017764

\section{Contents}

Introduction

James L. Conyers, Jr.

1. Black Consciousness, Pan-Africanism, and the African World History Project: The Case of Africana Studies for African Cultural Development
Greg E. Carr

2. A Genealogical Review of the Worldview Concept and Framework in Africana Studies-Related Theory and Research

Karanja Keita Carroll

3. Teaching Black Males: Cooperative Learning and the Problem of Implementation Serie McDougal, III

4. Cowboys of Color: The Perceived Sociocultural Significance of U2 Rodeo Demetrius W. Pearson

5. Heirs to Despair-ity: New Orleans, African Americans, and the Inconvenient Historical and Present-Day Truths Laid Bare by Hurricane Katrina Pamela D. Reed

6. Malcolm X's Leadership and Legacy: From the Grassroots to African Diaspora Andrew P. Smallwood 
alia, John McWhorter, Losing the Race "Self-Sabotage in Black America" (New York: Free Press, 2000); Winning the Race: Beyond the Crisis in Black America (New York: Gotham, 2005); Shelby Steele, The Content of Our Character: A New Vision of Race in America (New York: Harper, 1991); White Guilt: How Blacks and Whites Together Destroyed the Promise of the Civil Rights Era (New York: Harper Collins, 2006); Tavis Smiley, ed., The Contract with Black America (Chicago, IL: Third World Press, 2006); Michael Eric Dyson, Race Rules; Cornel West, Race Matters (New York: Vintage Press, 1994); Democracy Matters: Winning the Fight against Imperialism (New York: Penguin Press, 2004) among others.

30. See, inter alia, Theresa Perry, Claude Steele, and Asa Hilliard III, Young, Gifted and Black (Boston, MA: Beacon Press, 2003), vii-viii; Peter Murrell, African-Centered Pedagogy (Albany, NY: State University of New York Press, 2002), 155-70.

31. Amy J. Binder, Contentious Curricula: Afrocentrism and Creationism in American Public Schools (Princeton, NJ: Princeton University Press, 2002), 53-135.

32. Greg Carr, "Teaching and Studying the African(a) Experience: Definitions and Categories," in ed. Greg Carr, Lessons in African History (Philadelphia, PA: School District of Philadelphia, 2005), 1-2.

33. For the appearance of "class whiteness" and how this system works in South Africa, see Michael MacDonald, Why Race Matters in South Africa (Cambridge, MA: Harvard University Press, 2006), passim, esp. 5-14.

\section{2}

\section{A Genealogical Review of the Worldview \\ Concept and Framework in Africana Studies-Related Theory and Research}

\author{
Karanja Keita Carroll
}

\section{Introduction}

Daudi Ajani Ya Azibo's "Articulating the Distinction between Black Studies and the Study of Blacks: The Fundamental Role of Culture and the African-Centered Worldview" originally published in the Afrocentric Scholar and republished in both editions of Nathaniel Norment Jr's African American Studies Reader, provides much needed clarity on the philosophical foundations of Black Studies. ${ }^{1}$ However, Azibo's work is connected to an earlier project, Syed M. Khatib's (aka Cedric X. Clark) "Black Studies or the Study of Black People: Reflections on the Distinctive Characteristics of Black Psychology."2 Both Azibo and Khatib ask an important question related to the philosophical foundations of Black Studies. In a nutshell, how will the Africana Studies practitioner orient his/her research and analysis of Africana people, history, and culture? While both Azibo and Clark ask this question, Azibo clearly centers his answer on the usage of the African worldview. Azibo's work can be considered the first conscious usage of the worldview concept and framework within Africana Studies as it relates to the philosophical and conceptual foundations of the discipline. However, this is not the first usage of the worldview concept in Africana Studies-related theory and research. While acknowledging Azibo's role in bringing the worldview concept and framework into discussions related to the 
foundations of Africana Studies, it is arguably just as important to understand the manner by which the worldview concept has found its way into Africana Studies-related theory and research. While Azibo should be credited for consciously centering the philosophical foundations of Black Studies on the worldview framework, the worldview concept has a long history within Africana Studies-related theory and research, prior to Azibo's 1992 publication. ${ }^{3}$

As a project of Africana intellectual history, this chapter etches out the manner by which the worldview concept and framework has found its way into Africana Studies-related theory and research. One of the many pressing issues that currently impacts Africana Studies is the lack of work on intellectual history, especially as it relates to the philosophical foundations of the discipline. Arguably, without this type of research and investigation, Black Studies has the potential to be misdirected and misguided on a course which is incongruent with its intellectual, historical, and social origins. In an attempt to alleviate this travesty, this project functions as a model for navigating through the development of concepts, models, and theories within Africana Studies-related theory and research. This project intends to inspire new and future Africana Studies practitioners investigate critically the intellectual history of concepts, theories, and models that we argue are central to the disciplinary infrastructure and content of Africana Studies.

\section{Defining Africana Studies: Subject Matter, Perspective, and Goal/Function}

Definitions of Africana Studies have historically revolved around questions of subject matter, perspective, and function/goal. These three components make up the foundation of any definition of Black Studies. In regards to subject matter, we are concerned with clarifying whom and what is the focus of study within Africana Studies. The early students and professors of Black Studies insisted that the lives, experiences, and conditions of African-descended people consisted of a viable area of study. This was not to be engaged as a last-minute inclusion nor as a "problem," as was done in traditional academic disciplines prior to the $1960 \mathrm{~s}$, and in some instances today. These early advocates argued that the lives and experiences of African-descended people deserved to be the normative and primary focus of an academic program that they referred to as "Black Studies."

As Black Studies continues to expand, the subject matter has focused on investigating the culture of African-descended people.
By focusing on the culture of African-descended people, Africana Studies practitioners recognize the expansive and far-reaching implications of the concept of culture. Guided by Wade Nobles, Marimba Ani, Asa Hilliard, Jacob Carruthers, Molefi Kete Asante, Maulana Karenga, Clovis Semmes, and others, these scholars suggest that since culture impacts every aspect of human existence, the Black Studies practitioner is best suited at utilizing culture as the central focus and defining component of the subject matter within Africana Studies.

The question of perspective was another key concern of the early advocates of Black Studies. These students and scholars not only recognized that the lives, experiences, and conditions of Africandescended people were not considered a viable area of study in traditional academic disciplines, but these same advocates argued that it was necessary to engage the reality of African-descended people from their own social, historical, and cultural position. This clearly meant that the overarching interpretation of the lives and reality of African-descended people must be grounded in their own lived experience. Therefore, knowledge of African descendants impacts the perspective that is used because it functions as a point of reference and example of how people of African ancestry approached issues, problems, concerns, situations, etc. Historically and most recently, some scholars within Africana Studies have suggested that the concept of worldview be introduced within the question of perspective in the discipline. ${ }^{4}$ These scholars posit that given the expansive nature of the worldview construct, it is the most suitable perspective within the discipline that can give voice in clearly understanding the experiences of African-descended people. Far from being narrow and limited in scope, the African worldview allows for an overarching interpretation of African reality that is consistent with how African people have historically and contemporarily approached reality. ${ }^{5}$

Finally, the early advocates of Black Studies were not interested in investigating Africana reality from the experience of Africana people just for the sake of it. These early pioneers recognized the functional nature of education, knowledge, and consciousness and they argued that students and practitioners of Black Studies must be concerned with using knowledge gained in an academic setting to transform the lives of Black people, the Black community, and arguably humanity. Through the processes of knowledge production, transforming consciousness, and motivated action, the early advocates of Black Studies attempted to construct consciously a discipline that was concerned 
just as much with the creation and reorganization of knowledge on the Africana lived experience, as it was with applying and utilizing that knowledge as an agent of social change. ${ }^{6}$

As the early advocates of Black Studies demanded Black Studies programs and departments around the three components of subject matter, perspective, and function/goal, they inevitably provided the basis for future definitions of the discipline. While a variety of definitions can be found in the corpus of Black Studies scholarship, most early advocates of Black Studies would agree that Black Studies could generally be defined as the study and analysis of the Africana experience from their own sociocultural and historical position, with the aim of changing the lives of African-descended people. Stated differently and more in tune within recent developments within African-centered approaches to Africana Studies, Africana Studies is better understood as a critical analysis of Africana experiences, people and culture from the perspective of the African worldview, with the ultimate goal of changing the life chances of African-descended peoples and by extension humanity. This definition of Africana Studies is grounded within the historical call for Black Studies and is also reflective of the recent advances within African-centered theory and methodology.

One reason for explicitly defining Black Studies is to clearly distinguish and locate the variety of intellectual projects that take place within the western academy under the guise of "Black/Africana Studies scholarship." Arguably, a good portion of the recent theory and research that takes place in many departments and programs of Africana Studies can be categorized as "Africana Studies in name only" (ASNO). ASNO refers to scholarship on and about Africandescended people that is disconnected from the social, political, and ideological foundations of Black Studies, as expressed by the early practitioners and advocates of the discipline. Many of these projects do more harm than good in clearly etching out the disciplinary space in which Black Studies is currently located and thus leads to further confusion on the nature of Black Studies. One goal of newly trained Africana Studies practitioners is to advance Africana Studies theory and research, which is discipline-grounded and discipline-specific. These two concepts suggest that discipline construction and validation is a conscious process by which scholars, advocates, and practitioners knowingly create theories, concepts, models, and paradigms grounded within particular disciplinary confines.
While a good portion of Africana Studies scholarship can fall under the umbrella of ASNO, another portion can be considered as "Africana Studies Related." This refers to scholarship that has been produced on and/or about Africana people that is congruent with the aims and intentions of the early practitioners of Black Studies, but is not explicitly stated as Africana Studies scholarship. This corpus of work provides the foundation for many projects within Africana Studies and is continuously utilized as the basis for theory production within certain quarters of the discipline.

\section{Intellectual History and the Role of Genealogical Analysis in Africana Studies}

Current and future generations of Africana Studies practitioners are beset with a number of problems that have the potential of stunting the growth of the discipline. One such issue is the lack of intellectual history work being produced within the discipline. Africana intellectual history as a subcomponent of Africana History is fertile ground for the interrogation and investigation of the theoretical, paradigmatic, and philosophical foundations of the discipline. ${ }^{7}$ The application of our scholarly abilities in the investigation of the movement of ideas, concepts, models, etc., within the discipline can lead to clarification on what Black Studies has been about prior to its institutionalization in 1968.

Arguably, the next generation of Africana Studies scholars must attempt to clarify the complete intellectual history of the discipline. By grounding ourselves in how African people have approached education and knowledge production across space and time, we will be able to see the early remnants of Africana Studies that can be found throughout the western hemisphere, Asia, Europe, and any other place where African people have willingly and unwillingly ventured. However, most importantly, we can find the continental and traditional African components of the intellectual history of Africana Studies that link education and knowledge production with its cultural parent in African intellectual history. While this is clearly an expansive project, this current work attempts this process through an investigation of the worldview concept and framework in Africana Studies-related theory and research.

Influential to the structure and approach of this project is the work of Greg Kimathi Carr. Specifically, his "African-Centered Philosophy of History: An Exploratory Essay on the Genealogy of Foundationalist 
Historical Thought and African Nationalist Identity Construction," has provided a systematic approach in the development of an Africancentered genealogy of knowledge and knowledge production for African-centered scholars in Africana Studies. ${ }^{8}$ Carr is fundamentally concerned with the process by which ideas, concepts, assumptions, and theories pass along a Pan-African intellectual continuum and how these ideas then inform current intellectual and philosophical trends in African-centered research.

By revisiting the work of influential African-centered scholars, Carr develops a connective web of ideas and thinkers, which provides a useful map in laying out the development of an African-centered philosophy of history. While Carr's focus is on an African-centered philosophy of history, his general attention to the creation of a genealogy is of most importance. Carr's usage of the concept of genealogy is reflective of a historical continuum across space and time throughout the African world. This understanding deviates from the common Eurocentric notion, which is defined as "[a] form of historical analysis... [that] opposes th[e] traditional impulses of historical methods that attempt to discover continuity and patterns of development." Instead, the western notion of genealogy concerns itself with "ruptures, discontinuity, and surfaces, attempting as Michel Foucault has written, to 'record the singularity of events outside of any monotonous finality."' Consistent with this understanding of a Eurocentric genealogy is the importance of ruptures and discontinuity. However from an African-centered perspective, it is paramount that we look for continuity and interconnected relationships as a formidable aspect of cultural connections among African people across space and time. Therefore, Carr emphasizes the importance of historical continuity, cultural commitment, and honest scholarship for current and future African-centered scholars. All three of the previously mentioned components are essential within Africana Studies, and all Africancentered research endeavors. Furthermore, Carr provides a mandate for each generation of African-centered scholars, in that it is the role of each of us to reconnect our ideas to those that have come before, so future generations of scholars are able to see the development and movement of African-centered thought, practice, and scholarship across space and time.

Arguments regarding genealogies of knowledge and knowledge production among African-centered scholars are extremely relevant to Africana Studies, in that those who question the validity of the discipline do so on some of the most specious grounds. Questions of intellectual validity, historical depth, relevance, etc., are quickly put in their proper context when we are clear on the development of ideas, concepts, and theories that we claim are central to our discipline. Furthermore, all too many times scholars within Africana Studies are under the impression that we have developed new and cutting-edge arguments, but in actuality, we are all mostly ignorant of the discipline's inception and thus fail to recognize that a good portion of these arguments were originally articulated by the founding mothers and fathers of the discipline. Genealogical work within Africana Studies rectifies these pressing problems for both critics and advocates of the discipline.

\section{Worldview: Clarifying a Concept, Framework, and Nomenclature}

The worldview concept and framework has been utilized by a variety of scholars in and out of Africana Studies. According to Mack Jones, "people have a worldview that is a product of [their] lived experience and that constitutes the lens through which the world of sense perceptions is reduced to described fact."10 Marimba Ani summarily argues that "a worldview refers to the way in which people make sense of their surroundings; make sense of life and of the universe."11 While this is how worldview is understood generally, other scholars have argued that a worldview specifically reflects a set of philosophical assumptions. ${ }^{12}$ In doing so, a worldview investigates questions of cosmology, ontology, axiology, epistemology, teleology, logic, and other related philosophical assumptions which contribute to determining the way people make sense of reality and their lived experience.

The varied ways in which worldview is discussed suggests that it is understood in two manners. One group of scholars discusses worldview as a concept, while others discuss worldview as a framework. Both approaches in defining worldview are valid and actually build upon one another. Therefore, this analysis will rely upon the worldview construct as both a concept and as a framework.

Concepts, frameworks, and theories are central to the knowledge production process. Both frameworks and theories begin with concepts. Concepts function as the means for etching out specific definitional criteria for a given phenomenon. In this instance, worldview has functioned as a concept for scholars who have been interested in understanding the ways in which cultural understandings of reality 
impacted the lived experiences of a cultural group. As a concept, one's worldview refers to general human phenomenon, which is used in a broad sense to understand ones lived reality.

Scholars have also attempted to articulate worldview as a framework. A framework within this instance refers to a set of conceptual assumptions that work together in explaining the relationship between a given set of concepts. The worldview framework consists of concepts such as cosmology, ontology, axiology, epistemology, and other philosophical assumptions. Together, a cultural group's understanding of the universe (cosmology), nature of being (ontology), values (axiology), and knowledge (epistemology), all contribute to the ways in which a people make sense of their reality, i.e., their worldview.

Thus the notion of worldview within Africana Studies-related theory and research has engaged worldview as both a general concept and a more specified framework. The majority of this discussion has been complimentary and thus leads to the conclusion that worldview within Africana Studies is best understood as both a concept and framework.

It is also important to note that there has been a variety of nomenclature used to discuss the concept of worldview, whether African/ European, Afrocentric/Eurocentric, African-centered/Europeancentered or Optimal/Suboptimal. While there may be minor distinctions between each set of terms used, the substantive differences between each center on particular schools of thought rather than truly substantive distinctions. However, it should be clear that in most cases the African worldview is complimentary to what others may refer to as the Afrocentric/African-centered/Africentric/optimal worldview and the European worldview is complimentary to what others may refer to as the Eurocentric/European-centered/Euro-American/suboptimal worldview.

\section{A Genealogy of the Worldview Concept and Framework in Africana Studies-Related Theory and Research}

Almost all discussions of the worldview framework that can be found within Africana Studies-related theory and research stem from the work of Vernon Dixon. ${ }^{13}$ Vernon Dixon was originally trained in economics and earned his Ph.D. from Princeton University. Dixon's discussion of the worldview framework centered on the concepts of axiology, epistemology, and logic. These three concepts provided the foundation for Dixon's early arguments around the existence of a distinct Euro-American worldview and African worldview. These ideas were originally introduced in a 1971 publication for the Review of Black Political Economy entitled "African-Oriented and Euro-AmericanOriented Worldviews: Research Methodologies and Economics."14 However, it was Dixon's 1975 appearance at the J. Alfred Cannon Research Conference Series held at the Fanon Research and Development Center in Los Angeles, California, that provided exposure of his theorization around worldview differences and their impact upon research methodology. Dixon's presentation and future publication entitled "Worldviews and Research Methodology", was soon referenced by key members of a group of scholars who would eventually refer to themselves as the "Black Psychologists." Na'im Akbar, Cedric X (Clark), Lewis M. King, and Wade W. Nobles, who attended the conference, were members of this radical wing of the newly developing field known as "Black Psychology." Their arguments around the existence of a distinct field of study known as "African Psychology," while not explicitly informed by Dixon's argument regarding worldview, can be clearly understood as connected and related. ${ }^{15}$

Within the discipline of Political Science, Mack Jones began to develop arguments around the notion of distinct worldviews during the mid-1970s. Engaging worldview on a methodological level as Dixon did, Jones attempted to investigate how the worldview concept impacts the development of academic disciplines and the negative consequences this has on investigating the experiences of African-descended peoples. According to Jones, "The establishment of academic disciplines, then, is a normative purposeful exercise, the content of which is determined by a people's worldview and normative assumptions." ${ }^{16}$ Jones' concern with the development of academic disciplines and their relationship to worldview becomes essential as later discussants within Africana Studies attempt to rely upon the worldview concept and framework as an essential component for determining the disciplinary perspective of Africana Studies.

Building upon the work coming out of the J. Alfred Cannon Research Conference Series and the previous research of Mack Jones, Wade Nobles expanded on the discussion of worldview, finding it necessary to discuss the concepts of frame of reference and normative assumptions in conjunction with worldview. As early as 1978, Nobles advanced an African-based scientific network. Nobles argued that we should "build our theoretical and empirical analysis from our worldview, normative assumptions, and frame of reference." ${ }^{77}$ In doing so, 
Nobles provided a necessary advancement in understanding Africana people, culture, and experiences.

According to Nobles, three critical components constitute the African scientific paradigm: worldview, a set of normative assumptions, and frame of reference. Nobles further states,

In addition to answering specific questions such as who are we? Where did we come from? etc., a world-view also defines what people believe to be their 'nature' and the way in which they believe the world should operate. Growing directly out of their world-view, the normative assumptions of a people summarize their perceptions of the nature of the 'good life and the political, economic, and cultural forms and/or processes necessary for the realization of that life, A people's frame of reference, which is more directly related to academic disciplines and scientific inquiry, serves as the 'lens' through which people perceive the experiential world. ${ }^{18}$

A worldview determines the nature of reality, i.e., how a culture understands the nature of reality. Normative assumptions then determine how reality is perceived. Finally, a frame of reference determines the manner in which this reality should be understood and/or interpreted. As Nobles and Jones argue, worldviews, normative assumptions, and frames of reference, clearly impact the nature of disciplines, ${ }^{19}$ and Africana Studies is no different. ${ }^{20}$ Jones provides clarity for this point by stating that,

The establishment of academic disciplines, then, is a normative purposeful exercise, the content of which is determined by a people's worldview and normative assumptions. It is the process by which it determines what facts form the universe of facts should be selected and aggregated for study. The content of disciplines is determined by the third dimension of the web, the frame of reference.

Nobles adds clarity to the frame of reference, by stating that,

It particularly determines the formation of major concepts, propositions and theories appropriate to the examination of reality. In fact, it prescribes the assumptions and issues which will be considered as 'legitimate' areas of study, as well as how they should be studied.22

Nobles, clearly influenced by Jones, opened the floodgates for a clear methodological approach to Africana Studies. Grounding the work within the concept of worldview, not only he further suggests the necessity of normative assumptions, and how both of these inform a frame of reference.

Following Dixon's work, the worldview concept and framework was utilized in Africana Studies-related theory and research through the likes of not only Wade Nobles and Mack Jones, but also others in cluding Johnella Butler, Dona Richards (aka Marimba Ani), and Jacob Carruthers. All of these scholars independently and collectively relied upon the construction of a unique worldview orientation specific to people of African descent.

Johnella Butler's "Black Studies: Pedagogy and Our Adventure with Western Culture," presented in 1979 at the Harvard University Department of African American Studies Lecture Series and the Association for the Study of Afro-American Life and History conference, reached back to Dixon's earlier discussions of worldview and related these issues to pedagogy within Black Studies. ${ }^{23}$ Butler's major concern centered on the potential impact the worldview framework might have on the development of a discipline-specific pedagogy.

Dona Richards critique of European research methodology, as outlined in "The Ideology of European Progress," constructed a symbolic relationship between ideology and worldview. ${ }^{24}$ Jacob Carruther's "Reflections on the Afrocentric Worldview," originally published in 1979 in the Black Books Bulletin and republished in his Intellectual Warfare, began to connect the work of Cheikh Anta Diop to discussions of the worldview concept as a potential explanation for worldview differences. These ideas were expanded by Joseph Baldwin (aka Kobi Kambon) as both Carruthers and Kambon were early members of the Chicago African-centered movement. ${ }^{25}$ Carruthers argued that a close reading of Cheikh Anta Diop's The Cultural Unity of Black Africa provides a suitable foundation for explaining worldview differences. Furthermore,

The African worldview, modified to account for modern conditions, is the only viable foundation for African liberation. Wherever re cords still exist the wisdom of African people proclaims the necessity of the restoration of the African worldview as the necessary condition for liberation. An assessment of history demonstrates that when the principle has followed, liberation struggles have gone forward. In contrast, retrogression has taken place when the principle has been abandoned. ${ }^{26}$ 
Carruthers goes on to suggest that knowledge of this authentic worldview has been found consistently from Kemetic civilization to early African American thinkers, including Hosea Hudson, Edward Wilmont Blyden, and Henry McNeal Turner.

Thus prior to 1980, the worldview concept and framework was used by a number of key contributors to the newly developing discipline of Black Studies. Nobles, Jones, Richards, and Carruthers utilized a construction of worldview as a general concept that was applicable in the assessment of African life, history, and culture within America. Butler clearly relying upon the work of Dixon, articulated an understanding of worldview as a conceptual framework with its own components, which she felt were useful in the construction of a unique disciplinary pedagogy for Black Studies.

In the 1980s, the worldview concept and framework received continued attention within Africana Studies-related theory and research. Scholars continued to articulate the importance of the worldview framework as a viable tool in the accurate assessment of the lived experience of African peoples. The methodological concerns of worldview were stressed and the possibility of the origin of worldview differences were also presented. However, it was clear that the 1980s saw a discussion of worldview explode among those trained as psychologists. Arguably this was contingent upon the relationship of Vernon Dixon, Na'im Akbar, Wade Nobles, and others within Africancentered psychology, all who saw the methodological importance of the worldview framework.

Molefi Kete Asante's edited volume Contemporary Black Thought included two important essays which spoke to the relevance of the worldview concept, both in a general and specific sense. Joseph Baldwin's (aka Kobi Kambon) "The Psychology of Oppression" and Dona Richard's "European Mythology: The Ideology of 'Progress" engaged the negative impact of the European worldview on the lived reality of African-descended people. These essays also stressed the importance of being conscious of the African worldview as a useful tool in combating the normative assumptions of the European worldview. As Richards argues, "It is critical, therefore, that we in Africana Studies devote more of our energies to revealing the mythological, ideological and value aspects of concepts like the idea of progress, so that they can no longer be used to enslave African people psychologically and ideologically." ${ }^{27}$ However, this can only be done by having a clear grasp of worldview manifestations as found within the current world order.
Jacob Carruther's Essays on Ancient Egyptian Studies continued to rely upon the concept of worldview as it related to the African origin of Kemetic civilization, but more importantly it looked at the relevance of the worldview concept as impacting the methodological components of an African-centered historiography. Carruthers further developed those ideas that were discussed in his 1979 publication in the Black Books Bulletin and going even further, he argued that "...the formulation of an African worldview is the essential beginning point for all research which is based upon the interests of African people. There can be no African history, no African social science without an African worldview. By African, I do not mean merely a history or social science of Africa but a world history and a universal method of analysis designed by and for Africans."28 Again, Carruthers stressed that reliance upon the work of Cheikh Anta Diop was essential in the construction, application, and utilization of the African worldview. Through the recognition of the interplay of environment, culture, and philosophical assumptions, Carruthers' usage of Diop's work became the explanatory basis for worldview differences. Carruthers' theoretical explanation of worldview origins and differences provided fertile ground for the work of others who attempted to extend these arguments, most notably Kobi Kambon who would rely upon similar arguments as an explanation for the origin of worldview differences. ${ }^{29}$

Clearly the 1980s saw the increase in worldview discussions and usage among Black psychologists. Rather than discussing worldview in a general sense these scholars attempted to expand the concept. Using Dixon's framework as a model, these scholars argued that a worldview consisted of a set of philosophical assumptions revolving around questions of culturally specific cosmologies, ontologies, axiologies, epistemologies, and logics. ${ }^{30}$ In doing so, these scholars contributed to the movement of worldview, as discussed within Black Studies circles, from a general concept to a conceptual framework.

Important to the discussion of worldview within these academic circles, was a clear operationalization of the concept of culture. Wade Nobles' definition seemed to receive attention within certain circles and as the 1990s would suggest, his definition was easily relatable to the concept of worldview. According to Nobles, culture refers to "a general design for living and patterns for interpreting reality."31

Exemplary of this trend in Black psychology are the works of Na'im Akbar, Joseph Baldwin, Linda James Myers, and Wade Nobles. Na'im Akbar's "Evolution of Human Psychology for African Americans," 
relied upon the worldview framework as a critique of traditional western psychology and also as the basis for the development of a human psychology that was applicable to people of African descent. Joseph Baldwin, Reginald Hopkins, and Linda James Myers provided the first empirical assessments of the validity of the worldview concept and framework. These developments solidified worldview's usage as a methodological tool which could not only be used to understand Black psychological phenomenon, but as the 1990s would suggest, the worldview framework functioned as a tool useable to investigate the varied levels of human experiences.

In 1988, Linda James Myers publication of Understanding an Afrocentric Worldview: Introduction to an Optimal Psychology reflected a synthesis of earlier theoretical and empirical work Myers had created around the application and utilization of the worldview concept and framework. ${ }^{32}$ It is in fact through Myers that notions of an optimal and suboptimal worldview are introduced into the literature.

Two of the earliest attempts within Africana Studies-related theory and research to move toward testing the empirical validity of the worldview framework would take place within the early 1990s. Following the publication of Linda James Myers Understanding an African Worldview, Derek Montgomery, Mark Fine, and Linda James Myers published their preliminary findings on the construction of an instrument to assess an optimal Afrocentric worldview. Relying on the concepts of worldview, ontology, values, logic, identity, acquisition of knowledge, and sense of worth, Montgomery et al. constructed the 31-item Belief Systems Analysis Scale (BSAS) to assess the empirical validity of "an Afrocentric worldview as defined by optimal theory." The findings of Montgomery et al. "suggest that the BSAS has promising internal consistency and construct validity." While the findings were only preliminary they did reflect the movement toward testing the empirical validity of the worldview concept and framework.

Joseph A. Baldwin and Reginald Hopkins also contributed to the development of a measure to test the empirical validity of the worldview framework, based upon Baldwin's previous theorization on worldview. Like Montgomery et al., Baldwin and Hopkins began preliminary research on the construction of an instrument to measure the validity of the worldview framework and differences between Euro-American and African American worldviews. Relying upon the concepts of ethos, values, customs, and psycho-behavioral modalities, Baldwin and Hopkins constructed the 26-item Worldview Scale which was administered to Black and White college students. As Baldwin and Hopkins argued, "The findings of this preliminary research clearly suggest support for the notion that cultural differences may indeed exist between Black and White Americans, indexed by the construct of worldview." While both the findings of Montgomery et al. and Baldwin and Hopkins were only preliminary, they did set the stage for future developments in testing the empirical validity of the worldview concept and framework.

The 1990s also saw the revisiting of the worldview concept and framework from some of earlier voices, including Mack Jones and Vernon Dixon. Jones continued in his application of the worldview concept to an understanding of the political realities of Africandescended peoples in America. ${ }^{36}$ Dixon expanded on the epistemological component of the worldview framework in his comparison of culturally specific ways of knowing. ${ }^{37}$ Related to issues of epistemology, T. Owens Moore attempted an expanded discussion of affect-symbolic imagery in the pages of the Journal of Black Psychology. ${ }^{38}$ Marimba Ani also expounded on the epistemological component of worldview, along with the possible origins of worldview differences, among other areas in her foundational text Yurugu: An African-Centered Critique of European Cultural Thought and Behavior. ${ }^{39}$ Building off of similar arguments made by Johnella Butler, Delores Aldridge engaged the worldview concept as it related to pedagogical issues within Black Studies. ${ }^{40}$ And Gloria Joseph, while discussing the relevance of a Black Feminist pedagogy also investigated the manner by which issues of worldview impact pedagogy."

William Curtis Banks, in 1992 published "The. Theoretical and Methodological Crisis of the Africentric Conception," in which he argued that the development of an Africentric research methodology was stymied for a number of reasons. One that was clearly connected to discussions of worldview was the lack of a teleological dimension within the worldview framework. Banks argues that "the absence of a dimension within the Africentric framework of what traditionally is called teleology deprives the framework of an essential source of justification for programs of African-American development." 42 Banks, correctly states that African people have consistently held a "sense of directedness, of definite ends, of definite purpose". which we can understand through "the sense of commitment and extended investment that characterize" an African notion of self. ${ }^{43}$ Adding this component to the worldview framework extended it beyond 
discussions of cosmology, ontology, epistemology, and logic. In doing so, Banks' critique of the previous discussions of the worldview framework in fact expands its usage and relevance for the Africana Studies practitioner.

Mack Jones" 1992 publication "Political Science and the Black Political Experience: Issues in Epistemology and Relevance," engages some very important points for Africana Studies practitioners. Most important, is for Africana Studies to clearly recognize and accept that, "Academic disciplines, especially social science disciplines, are developed within the constraints of worldviews." ${ }^{34}$ While not included in his works cited list, Azibo was clearly aware of this previously stated fact. In his attempt to distinguish between "Black Studies" and the "Study of Blacks," Azibo maintains "that what Black Studies 'Black' is the usage of the conceptual universe afforded by the African worldview...in studying any and all manner of phenomena." ${ }^{\text {"45 }}$ Thereby, the African worldview has implications in all areas of the discipline, from its actual disciplinarity, origin, structure, content, purpose, and conceptual framework. ${ }^{46}$

According to Azibo, the disciplinary basis of Africana Studies can be found through the usage of the African worldview which makes the work of the discipline "culturally centered." ${ }^{47}$ By recognizing Africana Studies as a cultural science, Azibo argues that within Africana Studies there are no artificial boundaries ${ }^{48}$ as found within "white studies."49 Therefore, the disciplinary basis of Africana Studies is based upon the subject matter of Africana people, culture, and experience, which western disciplines do not properly engage. ${ }^{50}$

The African worldview also rectifies the question of disciplinarity within the field. According to Azibo "it is inescapable that Black Studies is both an interdisciplinary field and a singular discipline. The African worldview base of Black Studies eliminates any seeming contradiction on this point. It renders moot the unidiscipline vs. multidiscipline vs. interdiscipline issue that some writers pursue." ${ }^{1}$

As stated above, Azibo also argues that the African worldview is the basis by which we can validate the ancient African conception of Africana Studies. He maintains that "Black Studies began as a discipline at the time the Nile Valley Africans coalesced the manifold dictates of the African worldview into a systematic epistemological based and applied it in extant pedagogy."52 While stated with a high level of verbosity, Azibo is merely stating that the origins of Africana Studies can be found within the Nile Valley, where Africans utilized the African worldview as a pedagogical and intellectual tool for their interpretation of their reality.

Regarding the implications of the African worldview for the structure and content of Africana Studies, Azibo argues that the "artificial boundaries that separate so-called disciplines (psychology, religion, sociology, etc.)" must be avoided. ${ }^{53} \mathrm{He}$ thereby suggests that there should be no separation between African/Black psychology, Africana philosophy, and Africana religion, "because each owes [their] existence and unfolding to the dictates of the African worldview."54

Finally, regarding the conceptual framework of Africana Studies, Azibo rectifies discussions of Afrocentricity by certain scholars, and their progeny, who have provided vague, ahistorical, and intellectually disingenuous conceptualizations of this important component of Africana Studies. ${ }^{55}$ Gloria Joseph defines a conceptual framework as

those philosophical constructs used to define and structure reality, and is therefore basic to the way in which we perceive and interpret It is the basis of our worldview. All people have a conceptual system usually shaped for the most part by the culture with which they identify. ${ }^{56}$

In clarifying the concept of Afrocentricity as a conceptual framework, Azibo states

A matured apprehension of the concept of Afrocentricity reveals its meaning to be no more or less than construing, interpreting, negotiating, and otherwise acting on the world using the system of conceptual thought generated from the African cultural deep structure, also known as the African worldview. ${ }^{57}$

Therefore, Afrocentricity can be easily understood as using the African worldview to understand all manner of phenomena.

Azibo returns to these points in "Africentric Conceptualizations as the Pathway to African Liberation."58 Integral to centric thought (Africentric, Eurocentric, Asian-centered, etc.) are the concepts of social theory and survival thrusts. "A people's authentic social theory is essential to their basic philosophical and consequential psychological orientations." Furthermore, "A people's social theory is, in turn, reflected and realized in their 'survival thrust,' which may be defined as the characteristic ways a people negotiate the environment." 59 Both a people's social theory and survival thrusts define their centric thought base. 
The necessity of Africentric conceptualization in Africana Studies can be summarized in three key points. First, "Africentric conceptualization is the African's own original, primal, and indigenous way of interpreting reality and negotiating his/her material existence in it." 60 Given this, then the fact that the African worldview is the initial means of interpreting and negotiating the world, we should utilize it to construct models of thought and practice. Secondly, Azibo states, Africentric conceptualization "has proven itself to be the most efficacious orientation that correlates with African development, advancement and recoupment from wretchedness." ${ }^{\text {" Relying upon }}$ the scholarship of Jacob Carruthers, Azibo maintains that historically the use of the African worldview (i.e., Africentric conceptualization) has only led to our advancement as a people. It is, however, at the moment which we depart from our authentic thought based that "our wretchedness ensues." ${ }^{2}$ Third, given the "universal failure of alien (nonAfrican) thought-based conceptualizing to facilitate or correlate with the authentic development and recoupment of Africans, continental or diasporic," it is only in our interest to stay grounded within our own centric thought base. ${ }^{63}$ As Azibo has previously stated, "The African worldview is the answer. When Africans do not embrace it, our wretchedness ensues; when Africans cleave to it, sustentation and great achievements are attained" 64

The 1990 s also a considerable body of knowledge which infused the worldview concept and framework into the field of social work. Two leading proponents of this position have been Jerome Schiele and Mekeda Graham. ${ }^{65}$ For example, in "Afrocentricity as an Alternative Worldview for Equality," Schiele argues that "[t]o better understand inequality and its various manifestations, one should in the underlying of this society." 66 Thus relying upon concepts of cosmology and axiology, Schiele shows how European constructs of cosmology and axiology inform American social reality and become the philosophical basis of inequality within America. Schiele concludes by arguing that progressive social work must employ an alternative worldview framework that is in the interest of humanity and committed to human transformation.

Throughout the 1990 s a large body of scholarship was created which centered on defining, conceptualizing, and validating the reality of the worldview concept and framework. Scholars originally trained in psychology, political science, economics, anthropology, and other social science disciplines worked in creating a sizable body of knowledge focused on worldview. Those like Azibo, Aldridge, and a few others synthesized these discussions and brought them directly into scholastic arguments taking place in the continuously developing
discipline of Africana Studies.

As we move into the first decade of the twenty-first century there have been a number of worthwhile advancements in the usage of the worldview concept and framework, along with important advances in testing its empirical validity. As a synthesis of his previous work around the construction of an Afrocentric social work, Jerome Schiele published Human Services and the Afrocentric Paradigm which relies on the usage of the worldview concept and framework as the basis for the development of an Afrocentric social work. ${ }^{67}$

Kobi Kambon (aka Joseph Baldwin) published "The Worldviews Paradigm as Conceptual Framework for African/Black Psychology," a synthesis of his previous works around the worldview framework and its relation to African-centered Psychology ${ }^{68}$ Arguably, Kambon's work reflects a clear synthesis of the worldview concept discussed in the previously mentioned scholarship of Jacob Carruthers, along with the notion of a worldview framework which is consistent with discussions in African/Black psychology. Building upon the work of Vernon Dixon and Daudi Ajani ya Azibo, this author has attempted to reconnect the discussion of the worldview framework to Africana Studies, suggesting that Africana Studies requires a unique methodological framework and given the role of worldview within Africana Studies-related theory and research, the worldview framework has functioned as a perfect match. 69

Ezemanari Obasi, Lisa Flores, and Linda James-Myer have developed the most recent attempt at assessing the worldview framework and potential worldview differences in "Construction and Initial Validation of the Worldview Analysis Scale." Obasi et al. discuss the validity of the construction and utilization of the Worldview Analysis Scale (WAS) due to the prevalence of race-related measures which are unable to engage the foundational assumptions which inform human phenomena. Obasi et al. argue that "Although some research on racial constructs, such as racism, racialism, stereotypes, and race related stress to name a few, are very much needed to address the stimulus value that physical features might have on attitude formulation or well-being, a racial paradigm will have little to no utility when the researcher is interested in the cultural factors that influence spiritual, psychological, and/or behavioral phenomena." The WAS is a 45 -item scale revolving around "seven subscales: materialistic universe, 
spiritual immortality, communalism, indigenous values, tangible realism, knowledge of self, and spiritualism." ${ }^{\text {"2 }}$ Obasi et al.s findings contribute to previous attempts at empirically testing the validity of the worldview framework. Results from African, African American, European, European American, and multiethnic respondents validate clear worldview distinctions. Obasi et al. argue that "[a]lthough African Americans and European Americans life and interact together in the United States, they demonstrate significantly different worldviews that are linked to their cultural past which they may have little to no direct contact."73 These findings support the theoretical work of Jacob Carruthers, Wade Nobles, Na'im Akbar, Marimba Ani, Kobi Kambon, Daudi Azibo, and other African-centered scholars who have pioneered the construction of an African-centered perspective that is grounded within an African worldview.

\section{Conclusion}

This genealogical review of the worldview concept and framework within Africana Studies-related theory and research has attempted to revisit the development and usage of the worldview concept and framework within Africana Studies. In so doing, we have stressed the importance of genealogical analysis for Africana Studies research projects. By seeing the manner, development, and usage of particular concepts within Africana Studies, we provide the intellectual history and context for their future usage and development for research in the discipline. In hope of constructing discipline-specific concepts, constructs, and frameworks for Africana Studies, this analysis has attempted to function as an example of how we, as Africana Studies practitioners and researchers, can go about revisiting concepts that we posit to be central to the nature of our discipline. While not the final word on the worldview concept and framework within Africana Studies, it is the intention of this author that this project can contribute to the continued discussion of worldview and related concepts and/or frameworks that continue to advance Africana Studies as an autonomous academic discipline.

\section{Notes}

1. Daudi Ajani Ya Azibo, "Articulating the Distinction between Black Studies and the Study of Blacks: The Fundamental Role of Culture and the African-Centered Worldview," in The African American Studies Reader, ed. Nathaniel Norment (Durham, NC: Carolina Academic Press, 2001) $420-41$.
2. Syed M. Khatib, "Black Studies or the Study of Black People: Reflections on the Distinctive Characteristics of Black Psychology" in Black Psychology, ed. Reginald Jones (New York: Harper \& Row Publishers, 1980), $48-55$.

3. Ibid.

4. Karanja Keita Carroll, "Africana Studies and Research Methodology: Revisiting the Centrality of the Afrikan Worldview," Journal of Pan African Studies 2, no. 2 (2008): 4-27; Azibo, "Articulating the Distinction between Black Studies and the Study of Blacks."

5. lbid.

6. Philip T. K. Daniels, "Theory Building in Black Studies" in The African American Studies Reader, ed. Nathanial Norment (Durham, NC: Carolina Academic Press, 2001), 372-79.

7. I understand Africana Studies to be interdisciplinary followed by a subject-area model approach as discussed in the work of Maulana Karenga, Talmadge Anderson, and James Stewart.

8. Greg Kimathi Carr, "The African-Centered Philosophy of History: An Exploratory Essay on the Genealogy of Foundationalist Historical Thought and African Nationalist Identity Construction;" in The African World History Project-The Preliminary Challenge (Los Angeles, CA: ASCAC Foundation, 1997), 285-320.

9. See "genealogy" in Joseph Childers and Gary Hentzi, The Columbia Dictionary of Modern Literary and Cultural Criticism (New York: Columbia University Press, 1995).

10. Mack Jones, "Political Science and the Black Political Experience: Issues in Epistemology and Relevance," Ethnic Politics and Civil Liberties (1992): 30.

11. Marimba Ani, Let the Circle be Unbroken (New York: Nkonimfo Publications, 1980), 4 .

12. Vernon I. Dixon, "African-Oriented and Euro-American-Oriented Worldviews: Research Methodologies and Economics," Review of Black Political Economy 7, no. 2 (1971): 119-56; Vernon I. Dixon, "Worldviews and Research Methodology, in African Philosophy: Assumption and Paradigms for Research on Black Persons, ed. Lewis King (Los Angeles, CA: Fanon R \& D Center, 1976), 51-102; Kobi Kambon (aka Joseph Baldwin), The African Personality in America: An African-Centered Framework (Tallahassee, FL: Nubian Nation Publications, 1992); Kobi Kambon, "The Africentric Paradigm and African-American Psychological Liberation," in African Psychology in Historical Perspective and Related Commentary, ed. Daudi Ajani Ya Azibo (Trenton, NJ: Africa World Press, 1996), 57-69; Kobi Kambon, African/Black Psychology in the American Context: An African-Centered Approach (Tallahassee, FL: Nubian Nation Publications, 1998); Linda James Myers, "Expanding the Psychology of Knowledge Optimally: The Importance of Worldview Revisited" in Black Psychology, ed. Reginald Jones (Berkeley, CA: Cobb \& Henry Publishers, 1991), 15-32; Linda James Myers, Understanding an Afrocentric World View: Introduction to an Optimal Psychology (Dubuque, IA: Kendall/Hunt Publishing, 1988); William Curtis Banks, "The Theoretical and Methodological Crisis of the Africentric Conception," Journal of Negro Education 61, no. 3 
(1992): 262-72; Daudi Ajani Ya Azibo, "Africentric Conceptualizing as the Pathway to African Liberation," International Journal of Africana Studies 5 (1999): 1-31; Daudi Ajani Ya Azibo, "Articulating the Distinction between Black Studies and the Study of Blacks: The Fundamental Role of Culture and the African-Centered Worldview" in The African American Studies Reader, ed. Nathaniel Norment (Durham, NC: Carolina Academic Press, 2001), 420-41.

13. While there are others who have discussed and utilized the worldview framework and concept prior to Vernon Dixon, this analysis centers around him because of his impact on the development and usage of worldview as understood today.

14. Dixon, "African-Oriented and Euro-American-Oriented Worldviews."

15. Cedric X. Clark, D. Phillip McGee, Wade Nobles, and Luther X. Weem (aka Naim Akbar), "Voodoo or IQ: An Introduction to African Psychology," The Journal of Black Psychology 1, no. 2 (1975): 9-29.

16. Jones, "Scientific Method, Value Judgments, and the Black Predicament in the U.S." 12.

17. Nobles, "Toward an Empirical and Theoretical Framework", 683.

18. Ibid., author's emphasis, 682 .

19. Nobles, "Toward an Empirical and Theoretical Framework"

20. Jones, "Scientific Method, Value Judgments, and the Black Predicament." 21. Ibid., 12 .

22. Nobles, "Toward an Empirical and Theoretical Framework," 682.

23. Johnella Butler, "Black Studies: Pedagogy and Our Adventure with Western Culture" (paper presented at the Harvard University Department AfroAmerican Studies Lecture Series, Cambridge, MA, October 24, 1979 and at the Association for the Study of Afro-American Life and History meeting, October 27, 1979), ERIC document available ED183653.

24. Dona Richards (aka Marimba Ani), "The Ideology of European Dominance," Western Journal of Black Studies 3, no, 4 (1979): 244-51.

25. Carr, "The African-Centered Philosophy of History" 313-15.

26. Jacob Carruthers, Intellectual Warfare (Chicago, IL: Third World Press, 1999), 22.

27. Dona Richards, "European Mythology: The Ideology of 'Progress," in Contemporary Black Thought, ed. Molefi Kete Asante (Beverly Hills, CA: Sage Publications, 1980), 77.

28. Jacob Carruthers, Essays in Ancient Egyptian Studies (Los Angeles, CA: University of Sankore Press, 1984), 17.

29. Kobi Kambon (aka Joseph Baldwin), The African Personality in America: An African-Centered Framework (Tallahassee, FL: Nubian Nation Publications, 1992); Kobi Kambon, "The Africentric Paradigm and African-American Psychological Liberation," in African Psychology in Historical Perspective and Related Commentary, ed. Daudi Ajani Ya Azibo (Trenton, NI: Africa World Press, 1996), 57-69; Kobi Kambon, African/Black Psychology in the American Context: An African-Centered Approach (Tallahassee, FL: Nubian Nation Publications, 1998).

30. See reference note 15 .

31. Wade Nobles, Africanity and the Black Family (Oakland, CA: A Black Family Institute Publication, 1985), 102.
32. Linda James Myers, Understanding an Afrocentric World View: Introduction to an Optimal Psychology (Dubuque, IA: Kendall/Hunt Publishing, 1989).

33. . Derek E. Montgomery, Mark A. Fine, and Linda James-Myers, "The Development and Validation of an Instrument to Assess an Optimal Afrocentric Worldview," Journal of Black Psychology, 17, no. 1 (1990): 38

34. Ibid., 50

35. Ibid., 49 .

36. Mack Iones, "Political Science and the Black Political Experience: Issues in Epistemology and Relevance," Ethnic Politics and Civil Liberties (1992): 25-39.

37. Vernon J. Dixon, "Some Thoughts on Teaching Predominantly Affective Oriented Groups," in Introducing Race and Gender Into Economics, ed. Robin Bartlett (New York: Routledge, 1997), 177-89.

38. T. Owens-Moore, "Revisited Affect-Symbolic Imagery," Journal of Black Psychology 22, no. 4 (1996): 443-52.

39. Marimba Ani, Yurugu: An African-Centered Critique of European Cultural Thought and Behavior (Trenton, N]: African World Press, 1994).

40. Delores Aldridge, "The Kitchen is Filled-But Who are the Cooks? What it Takes to Teach Black Studies," Phylon 49, nos. 1-2 (1992):61-70.

41. Gloria Joseph, "Black Feminist Pedagogy and Schooling in White Capital ism America," in Words of Fire: An Anthology of African American Feminist Thought, ed. Beverly Guy-Sheftall (New York: New Press, 1995), 462-72

42. Banks, "The Theoretical and Methodological Crisis of the Africentric Conception," 266.

43. Ibid

44. Jones, "Political Science and the Black Political Experience," 30.

45. Azibo, "Articulating the Distinction between Black Studies and the Study of Blacks," 422

46. Ibid., $422-36$.

47. Ibid., 426.

48. Leahcim Semaj, "Towards a Cultural Science," in African Psychology in Historical Perspective and Related Commentary, ed. Daudi Ajani Ya Azibo (Trenton, NJ: Africa World Press, 1996), 193-202.

49. Azibo, "Articulating the Distinction between Black Studies and the Study of Blacks," 426.

50. While it is the position of this author that the disciplinarity of Africana Studies must go beyond the issue of perspective, Azibo is clearly on poin in his discussion of the African worldview as the distinguishing characteristic of Africana Studies, especially as compared to traditional academic disciplines.

51. Azibo, "Articulating the Distinction between Black Studies and the Study of Blacks," 427

52. Ibid., 428 .

53. Ibid, 426

54. Ibid.

55. Ibid.

56. Joseph, "Black Feminist Pedagogy and Schooling in White Capitalism America," 466 
57. Azibo, "Articulating the Distinction between Black Studies and the Study of Blacks", 432.

58. Azibo, "Africentric Conceptualizing as the Pathway to African Liberation."

59. Azibo, "Articulating the Distinction between Black Studies and the Study of Blacks" 1

60. Azibo, "Africentric Conceptualizing as the Pathway to African Liberation" 16.

61. Ibid., 17.

62. Azibo, "Articulating the Distinction between Black Studies and the Study of Blacks," 425.

63. Ibid, $17-18$.

64. . Ibid., 425

65. Jerome H. Schiele, "Afrocentricity as an Alternative Worldview for Equality," Journal of Progressive Human Services 5, no. 1 (1994): 5-25; Mekada Graham, "The African-Centered Worldview: Developing a Paradigm for Social Work," Journal of Black Studies 30, no. 1 (1999): 103-22.

66. Scheile, "Afrocentricity as an Alternative Worldview for Equality," 6.

67. Jerome Schiele, Human Services and the Afrocentric Paradigm (Binghamton, NY: Hawthorne Press, 2000).

68. Kobi Kambon, "The Worldviews Paradigm as the Conceptual Framework for African/Black Psychology," in Black Psychology, ed. Reginald Jones (Hampton, NY: Cobb \& Henry Publishers, 2004), 73-92.

69. Carroll, "Africana Studies and Research Methodology"

70. Ezemenari Obasi, Lisa Y. Flores, and Linda James-Myers, "Construction and Initial Validation of the Worldview Analysis Scale (WAS)," Journal of Black Studies 39, no. 6 (2009): 937-61.

71. Ibid., 938.

72. Ibid, 937.

73. Ibid., 956.

\section{Teaching Black Males: Cooperative Learning and the Problem of Implementation}

\author{
Serie McDougal, III
}

Culture bears upon every form of human thought and interaction, including but not limited to teaching and learning. Because America is home to a diversity of people and the unique cultural resources and orientations they bring with them, the "one size fits all" approach to teaching and learning undermines the social and academic potential of many students of color. Cooperative learning is among the learning styles that have often proven successful in increasing the academic achievement of African American learners (Boykin and Cunningham 2002; Jagers 1992; Willis 1989). Once certain teaching methods, such as cooperative learning, are found to be successful through research, it is often incumbent upon teachers to put those methods into practice. However, the research process itself must be not only exploratory and explanatory, it must also be evaluative. Evaluative research is necessary in learning style research because it allows one to study the implementation and practice of teaching strategies outside of the controlled environments of experimental designs and in the real world. The U.S. Department of Education defines cooperative learning in the following way:

Cooperative learning is a successful teaching strategy in which small teams, each with students of different levels of ability, use a variety of learning activities to improve their understanding of a subject Each member of a team is responsible not only for learning what is taught but also for helping teammates learn, thus creating an 